\title{
PEMBENTUKAN NILAI KARAKTER SISWA MELALUI \\ PEMBIASAAN MEMBACA AL-QUR'AN SDIT AL-ISLAM KAMPUNG SUNTU KOTA BIMA
}

\author{
Abd. Salam \\ STITSunan GiriBima \\ salamrahmania1234@yahoo.co.id
}

\begin{abstract}
Abstrak
Penelitian ini berkaitan dengan pembentukan bagi perkembangan pribadi seorang siswa SDIT Al-Islam Kampung Suntu Kota Bima. Dalam konteks ini, guru-guru di SDIT Al-Islam Kampung Suntu sangat dituntut untuk mengedapankan nilai-nilai karakter dan nilainilai Al-Qur'an bagi peserta didiknya/siswa sebagai wujud capaian akhir pembentukan moral dan akhlak seorang anakdidik. Peneliti ini merupakan penelitian lapangan dengan menggunakan pendekatan kualitatif yaitu suatu penelitian yang ditujukan untuk mendeskripsikan dan menganalisis fenomena, peristiwa, aktivitas sosial, sikap, kepercayaan, persepsi, pemikiran orang secara individual maupun kelompok. Berkenaan dengan hal tersebut, penelitian ini bertujuan untuk mengkaji; Bagaimana pembentukan karakter dan nilai-nilai al-Qur'an Siswa melalui pembiasaan membaca al-Qur'an di SDIT Al-Islam Kampung Suntu Kecamatan Rasanae Barat Kota Bima.
\end{abstract}

Kata Kunci : Nilai, Karakter, Al Qur'an.

\section{PENDAHULUAN}

endidikan karakter akhir-akhir ini semakin banyak
diperbincangkan di tengah-tengah masyarakat Indonesia,
terutama oleh kalangan akademisi. Sikap dan perilaku masyarakat dan bangsa Indonesia sekarang cenderung mengabaikan nilai-nilai luhur yang sudah lama dijunjung tinggi dan mengakar dalam sikap dan perilaku sehari-hari. Nilai-nilai karakter mulia, seperti kejujuran, kesantunan, kebersamaan, dan religius, sedikit demi sedikit mulai tergeres oleh budaya asing yang cenderung hedonistik, materialistik, dan individualistik, sehingga nilai-nilai karakter tersebut tidak lagi dianggap penting jika bertentangan dengan tujuan yang ingin diperoleh. Anas Salahudin dan Irwanto Alkrienciehie (2013: 49).mengatakan dalam buku Pendidikan Karakter, Pendidikan berbasis Agama dan Budaya Bangsa Menurut ajaran Islam, hakikat pendidikan 
adalah mengembalikan nilai-nilai ilahiah pada manusia (fitrah)dengan bimbingan Al-Qur'an dan As-Sunnah (hadits) sehingga menjadi manusia yang berakhlak mulia (insan kamil).

Berdasarkan tujuan dari pendidikan karakter pada baca AlQur'an tersebut, yaitu berupaya membentuk watak manusia yang memiliki sikap mental dan prilaku yang baik (akhlaqul karimah), manusia yang bermoral dan memiliki etika serta sopan santun, baik terhadap diri pribadi siswa, orang lain, lingkungan dan Tuhan. Maka penulis berusaha mengkaji PenanamanNilai-nilai Karakterdan nilai-nilai al-qur'an siswa melalui pembiasaan membaca al-qur'an sebelum belajar di SDIT Al-Islam kampung suntu kecamatan rasanae barat kota bima dan Al-Qur'an juga sebagai pembinaan karakter siswa-siswi SDIT AlIslam Kampung Suntu Kecamatan Rasanae Barat Kota Bima.

\section{Tinjauan Konsep Dasar Tentang Karakter}

Secaraetimologis, kata karakter (Inggris: character) berasal dari bahasa Yunani (Greek), yaitucharassein yang berarti "to engrave" (Ryan and Bohlin, 1999: 5).Kata "to engrave" bisa diterjemahkan mengukir, melukis, memahatkan, atau menggoreskan (Echols dan Shadily, 1987: 214).Dalam Kamus Bahasa Indonesia kata "karakter" diartikan dengan tabiat, sifat-sifat kejiwaan, akhlak atau budi pekerti yang membedakan seseorang dengan yang lain, dan watak.Karakter juga bisa berarti huruf, angka, ruang, simbul khusus yang dapat dimunculkan pada layar dengan papan ketik (Pusat Bahasa Depdiknas, 2008: 682).Orang berkarakter berarti orang yang berkepribadian, berperilaku, bersifat, bertabiat, atau berwatak.Dengan makna seperti ini berarti karakter identik dengan kepribadian atau akhlak.Kepribadian merupakan ciri atau karakteristik atau sifat khas dari diri seseorang yang bersumber

dari bentukan-bentukan yang diterima dari lingkungan, misalnya keluarga pada masa kecil, dan juga bawaan sejak lahir (Koesoema, 2007)

Secara terminologis, makna karakter dikemukakan oleh Thomas Lickona.Menurutnya karakter adalah "A reliable inner disposition to respond to situations in amorally good way. "Selanjutnya Lickona menambahkan, "Character so conceived hasthree interrelated parts: 
moral knowing, moral feeling, and moral behavior" (Lickona, 1991: 51). Menurut Lickona, karakter mulia (good character) meliputi pengetahuan tentang kebaikan, lalu menimbulkan komitmen (niat) terhadap kebaikan, dan akhirnya benar-benar melakukan kebaikan. Dengan kata lain, karakter mengacu kepada serangkaian pengetahuan (cognitives), sikap (attitides), dan motivasi (motivations), serta perilaku (behaviors) dan keterampilan (skills).

Dari pengertian di atas dapat dipahami bahwa karakter identik dengan akhlak, sehingga karakter merupakan nilai-nilai perilaku manusia yang universal yang meliputi seluruh aktivitas manusia, baik dalam rangka berhubungan dengan Tuhannya, dengan dirinya, dengan sesama manusia, maupun dengan lingkungannya, yang terwujud dalam pikiran, sikap, perasaan, perkataan, dan perbuatan berdasarkan norma-norma agama,hukum, tata karma, budaya, dan adat istiadat. Dari konsep karakter ini muncul konsep pendidikan karakter (character education).

\section{Internalisasi Nilai-nilai Karakter melalui Al-Qur’an}

Setiap orang yang akan melaksanakan tugasnya sebagai guru ngaji harus memiliki karakter, yang sesuai dengan ajaran Islam, sebagai guru ngaji dituntut memberi keteladan kepada Santri-Santriwati.Zakiah Daradjat, (1993: 98) mengemukakan bahwa Guru merupakan tokoh yang akan ditiru dan diteladani, dalam melaksanakan tugasnya sebagai pendidik, dia harus tabah dan tahu cara memecahkan berbagai kesulitan dalam tugasnya sebagai pendidik. Sebagai manusia biasa, guru ngaji tidak terlepas dari berbagai kesulitan hidup, kebutuhan hidup rumah tangga, pergaulan sosial dan keadaan ekonomi, kesejahteraan supaya tidak terganggu kelancaran tugas dalam proses belajar mengajar bacaan Al-Qur'an. Keadaan guru ngaji tersebut dapat memperkuat serta menumbuhkan karakter yang baik.Dalam proses penguatan karakter pada para siswa, berlangsung secara berangsur-angsur, bukanlah hal yang sekaligus terjadi melainkan sesuatu yang berkembang secara bertahap, upaya pembentukan karakter terhadap Santri-Santriwati merupakan suatu kegiatan proses akhir dari perkembangan fisik/psikis 
manusia yang berlangsung dengan baik, tentu akan menghasilkan suatu karakter yang harmonis.(Ahmad D. Marimba, 1989: 75).

Hidup manusia senantiasa mengandung unsur dinamisme yaitu perubahan-perubahan secara progresif untuk menuju suatu integrasi pada akhirnya melahirkan karakteristik. Ahmad D. Marimba (1989: 75) mengemukakan ada tiga yaitu: 1) Aspek kejasmaniaan; meliputi tingkah laku luas yang mudah nampak dan ketahuan dari luar misalnya cara-cara berbuat, cara-cara berbicara; 2) Aspek kejiwaan; meliputi aspek-aspek yang tidak segera dapat dilihat dan ketahuan dari luar misalnya cara berfikir, sikap dan minat; 3) Aspek keharmonisan yang luhur; meliputi aspek-aspek kejiwaan yang lebih abstrak yaitu filsafat hidup dan kepercayaan ini meliputi sistem nilai-nilai yang telah meresap didalam karakter itu, telah menjadi bagian dan mendarah daging dalam karakter itu yang mengarahkan dan memberi corak seluruh kehidupanm individu itu bagi orang-orang yang beragama. Aspek-aspek inilah yang menuntutnya kearah kebahagiaan, bukan saja didunia tapi juga diakhirat, aspek-aspek inilah memberi kualiatas karakter secara keseluruhannya.

Jadi karakter artinya kepribadian yang secara keseluruhan aspeknya, sebagai perilaku yang ditampilkan, sesuai dengan ajaran Islam aktifitas kejiwaannya, falsafah hidup dan kepercayaannya menunjukkan rasa pengabdian dan penyerahan diri kepada Allah Swt. Romantika AlQur'an Mengatakan: “Dan Sesungguhnya kamu benar-benar berbudi pekerti yang agung. (QS. Al-Qalam:4)".

Dari definisi ayat di atas dapat disimpulkan bahwa dalam menjabarkan karakter universal diperlukan bantuan pemikiran akal manusia dan kesempatan sosial yang terkandung dalam ajaran etika dan moral. Menghormati kedua orang tua misalnya adalah karakter yang bersifat mutlak dan universal. Sedangkan bagaimana bentuk dan cara menghormati orang tua itu dapat dimanifestasikan oleh hasil pemikiran manusia. Jadi, karakter Islam bersifat mengarahkan, membimbing, mendorong, membangun peradaban manusia dan mengobati bagi penyakit sosial dari jiwa dan mental, serta tujuan berkarakter yang baik untuk mendapatkan kebahagiaan di dunia dan akhirat. 
Dalam proses penguatan karakter terhadap siswa, guru bidang studi aqidah akhlak berupaya mewujudkan tiga aspek karakter tersebut secara harmonis yaitun aspek kejasmanian, aspek kejiwaan, dan aspek keharmonisan, dengan mewujudkan ketiga aspek tersebut dapat menciptakan keseimbangan yang terpadu secara integritas karakter. Yang dimaksud dengan integritas karakter ialah proses yang terpadu dari pembangunan karakter setiap manusia yaitu sesuatu pertumbuhan yang menumbuhkan kesatuan unsur-unsur jasmani dan rohaniah menjadi bangunan yang harmonis sebagai akibat terjalinnya mekanisme sistem pengaturan yang tertib, teratur dan rapi.(Suryapratondo, 1984).Selanjutnya, dalam menumbuhkan integrasi karakter manusia ini bacaan Al-Qur'an berproses dalam mendinamisasi susunan karakter manusia. Adapun susunan karakter manusia yang harus mendapat pengaruh perubahan pendidikan, adalah: 1) Membaca Al-Qur'an dapat mengantarkan kita masuk syurga; 2) Membaca Al-Qur'an dapat mengingat kita kepada Allah SWT; 3) Membaca Al-Qur'an dapat menentramkan jiwa; 4) Membaca Al-Qur'an sebagai obat penyakit hati; 5) Membaca Al-Qur'an sebagai pembersih hati; 6) Membaca Al-Qur'an sebagai petunjuk; 7) Membaca Al-Qur'an sebagai cahaya ilmu; 8. Membaca Al-Qur'an dapat dijadikan sebagai ibadah.

Dari uraian nilai-nilai Al-Qur'an di atas, bahwa nilai serta bacaan Al-Qur'an berperan secara kompak dan harmonis, yang dalam pandangan lain harus terwujud dalam bentuk "amal shaleh", amal shaleh yang dimaksudkan disini adalah buah iman, akhlak dan ilmu.Dalam alQur'an Allah banyak menyuruh manusia untuk beramal shaleh disegala bidang dan kebanyakan ayat bahwa amal dikaitkan dengan iman, seperti firman Allah sebagai berikut:

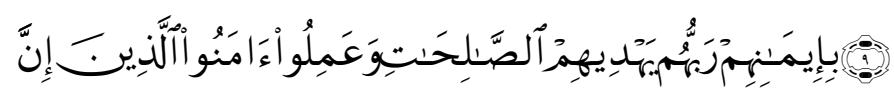

Artinya: "Sesungguhnya orang-orang yang beriman dan mengerjakan amal-amal saleh, mereka diberi petunjuk oleh Tuhan mereka karena keimanannya. (QS. Yunus: 9)".

Maksud ayat di atas adalah diberi petunjuk oleh Allah untuk mengerjakan amal-amal yang menyampaikan surga.Amal shaleh yaitu 
apa saja yang dilakukan manusia untuk mendapatkan keridhaan Allah Swt untuk dirinya sendiri, keluarga, sesama manusia dan makhlukmakhluk lain. Maka seseorang yang beriman, berakhlak mulia senantiasa berbuat baik penuh semangat keimanannya, dan senantiasa mengikuti petunjuk yang benar dan inilah karakter yang dikehendaki.

\section{Pembiasaan Membaca Al-Quran Dalam Pembentukan Karakter}

“Al-qur'an adalah" menurut pendapat yang paling kuat berarti “bacaan”, asal kata Qaraa.Kata Al-qur'an itu berbentuk masdar dengan arti isi maf'ul yaitu maqru (dibaca)."Menurut istilah Al-qur'an adalah "Kalam Allah SWT", yang merupakan mu'zizat dan yang ditulis dimushab dan diriwayatkan secara mutawatir serta membacanya adalah ibadah.Didalamnya terkandung ajaran pokok yang dapat dikembangkan untuk keperluan seluruh aspek kehidupan melalui Ijtihad.Ajaran yang terkandung dalam Al-qur'an terdiri prinsip dasar yaitu yang berhubungan dengan masalah keimanan yang disebut dengan Ibadah dan yang berhubungan dengan amal yang disebut "syari'at".Al-qur'an sebagai sumber aspirasi dan wawasan serta pandangan universal, memberikan dorongan motivasi manusia untuk mengembangkan ilmu pengetahuan melalui rasio (akal pikiran) sejauh mungkin sampai pada zat Allah yang tidak mungkin oleh rasio itu.(Departemen Agama RI,1989:5)

Setiap muslim mempunyai komitmen mengenal Al-Qur'an, mempelajarinya, mengamalkanya, dan mendakwahkannya. Dalam rangka mewujudkan komitmen ini Indonesia yangmayoritas penduduknya beragama Islam telah menjadikan Pendidikan Agama Islam sebagai salah satu mata pelajaran disetiap jenjang pendidikan formal.(Sukiman, 2013).Membaca Al Qur'an bagi umat Islam merupakan ibadah kepada Allah SWT. Oleh karena itu, keterampilan membaca Al Qur'an perlu diberikan kepada anak sejak dini mungkin, sehingga nantinya diharapkan setelah dewasa dapat membaca, memahami dan mengamalkan Al Qur'an dengan baik dan benar.Membaca Al-qur'an dengan tartil dan melagukan serta memperindahnya. Berdasarkan firmanya: 


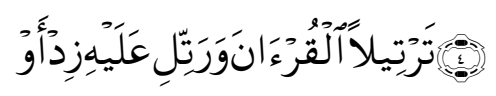

Artinya: "Dan bacalah al-Qur'an itu dengan tartil (perlahanperlahan)." (Al-Muzzammil:4).

Menurut Majid dan Dian Andayani (2011: 2), bahwasannya keberhasilan suatu bangsa atau anak itu sendiri dalam memperoleh tujuanya tidak hanya ditentukan oleh melimpah ruahnya sumber daya alam, tetapi sangat ditentukan oleh kualitas sumber daya manusia.Pendapat yang sama juga disampaikan Hasan Ibrahim (2002: 141) yang mengatakan, "Bangsa yang besar dapat dilihat dari kualitas/karakter bangsa (manusia) itu sendiri. Dalam sejarah Islam, sekitar 1400 Tahun yang lalu, Nabi Muhammad SAW, Sang Nabi terakhir dalam ajaran Islam, juga menegaskan bahwa misi utamanya dalam mengajar, mendidik, manusia adalah untuk menyempurnakan Akhlak, karna Akhlak Nabi itu sendiiri adalah Al-Qur'an, dan mengupayakan pembentukan karakter yang baik (Good Charakter).Pemberian pelajaran Al Qur'an sebaiknya melalui tri pusat pendidikan yaitu : keluarga, sekolah dan masyarakat, dimana yang paling dominan dan waktunya banyak adalah di dalam keluarga. Oleh karena itu yang paling menentukan berhasil/tidaknya anak dapat membaca Al Qur'an adalah pendidikan informal di tengah keluarga. Sebagaimana Allah berfirman:

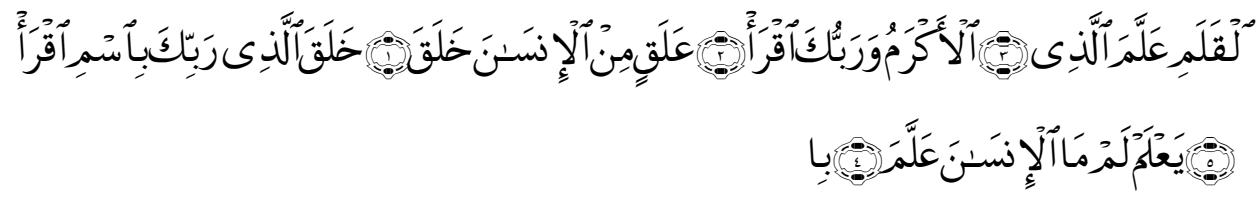

Artinya: bacalah dengan (menyebut) nama Tuhanmu yang Menciptakan. Dia telah menciptakan manusia dari segumpal darah. Bacalah, dan Tuhanmulah yang Maha pemurah, yang mengajar (manusia) dengan perantaran kalam. Dia mengajar kepada manusia apa yang tidak diketahuinya. (QS. Al-A'laq:1-5).

Maksud ayat di atas, dalam pandangan Mohd Alwi Yusoff, (2010) bahwa Allah mengajar manusia dengan perantaraan tulis baca. Membaca Al Qur'an bagi umat Islam merupakan ibadah kepada Allah SWT.Oleh karena itu keterampilan membaca Al Qur'an perlu diberikan kepada anak sejak dini mungkin, sehingga nantinya diharapkan setelah 
dewasa dapat membaca, memahami dan mengamalkan Al Qur'an dengan baik dan benar.Pendidikan dalam masyarakat juga penting, karena anak lebih banyak bergaul dengan masyarakat yang dapat mempengaruhi sifat, watak dan perilakunya sehari-hari.Karena pentingnya pengetahuan tentang Al Qur'an.Didalam metode Iqra dapat dijadikan sesebuah kaedah alternatif bagi guru dalam pengajaran dan pembelajaran membaca al-Quran serta boleh menghantarkan murid mahir dalam membaca al-Quran.Bacaan al-Qur'an di kalangan pelajar yang dikaji tidaklah berada pada tahap yang terlalu lemah.Walau bagaimanapun, kelemahan dan ketidakupayaan sebilangan pelajar untuk membaca al-Qur'an dengan baik dan lancar sebenarnya memang wujud.

Pengajarandan pembelajaran al-Quran haditsmenggunakan metode Iqra dapat meningkatkan kemampuan pelajar dalam membaca alQuran, disamping itu, kaedah ini juga dapat meningkatkan kreatifitas pelajar dalam aktifiti pembelajaran dalam bilik darjah.Perkara di atas dapat dibuktikan apabila pelajar diajar menggunakan metode biasa berdasarkan statistik pada gelung pertama kemampuan pelajar hanya berada pada tahap sederhana (62\%).Apabila mereka diajar dengan menggunakan metode Iqra analisis statistik menujukkan kemampuan siswa dapat meningkat mencepai tahap cemerlang (92\%).(Rendi Abdulrohman, 2010).Oleh karena itu, bagi guru agama Islam selain mengajar pembelajaran al-Qur'an hadits dengan menggunakan metode iqro guru agama Islam mengajarakan Implikasi kajian ialah guru Pendidikan Islam perlu sentiasa mempertingkatkan kemahiran pengajaran Tilawah al-Quran yang mereka miliki dengan cara yang paling efektif agar murid dapat menguasai Tilawah al-Qur'an dengan berkesan. (Tarmizi. 2009: 93).Dengan adanya pengajaran bacaan alQur'an atau Pendidikan al-Quran dengan jelasnya membuktikan bahwa ajaran-ajaran yang terkandung di dalamnya mampu memberi kejayaan dalam berbagai penyelidikan

\section{METODE PENELITIAN}

Peneliti ini merupakan penelitian lapangan dengan menggunakan penedekatan kualitatif yaitu suatu penelitian yang ditujukan untuk 
mendeskripsikan dan menganalisis fenomena, peristiwa, aktivitas sosial, sikap, kepercayaan, persepsi, pemikiran orang secara individual maupun kelompok.Tempat penelitian dilaksanakan di SDIT Al-Islam, yang beralamat di Kampung Suntu Kota Bima.Proses pengumpulan data melalui wawancara, observasi, dan dokumentasi lapangan. Sedangkan, Dalam menganalisa data, peneliti akan menggunakan teknik deskriptif analitik. Hasil analisa berupa pemaparan gambaran mengenai situasi yang diteliti dalam bentuk uraian naratif.(Nana Sudjana, 1989: 197). Dengan demikian, analisis ini akan digunakan oleh peneliti untuk menganalisa tentang bagaimana internaslisasinilai-nilai karakter siswai melaui pembiasaan membaca Al-Qur'an di SDIT AL-Islam Kampung SuntuKota Bima.

\section{HASIL PENELITIAN DAN PEMBAHASAN}

Pembentukan Nilai Karakter Siswa Melalui Pembiasaan Membaca Al-Qur'an di SDIT Al-Islam.

\section{Nilai Integritas}

a. Mengajarkan anak untuk berbicara apa adanya dan tidak suka bohong

b. Mengajarkan anak untuk mengakui kesalahan bila telah berbuat salah

c. Menunjukan pada anak tentang sikap jujur baik pada diri sendiri, keluarga dan orang lain yang didasarkan pada: bila berkata tidak bohong, bila berjanji tidak ingkar dan bila dipercaya harus bertanggung jawab

d. Menanamkan sikap jujur kepada anak harus diimbangi dengan perbuatan yang menjadi penilaian bagi diri sendiri dan menjadi contoh teladan bagi orang lain

e. Mengajarkan untuk selalu mengatakan sesuatu yang benar sekalipun pahit

f. Mengajarkan pada anak yang benar akan tetap dan yang benar akan mengantarkan orang untuk dipercaya

g. Membiasakan anak untuk memegang teguh pada komitmen dan tanggung jawab 


\section{Nilai Nasionalis}

a. Menanamkan nilai kebangsaan kepada anak, bangga menjadi orang Indonesia lebih khusus orang bima

b. Menanamkan nilai rela berkorban sebagai anak bangsa Indonesia, mengutamakan kepentingan bangsa dan negara, di atas kepentingan induvidu dan golongan

c. Mengisi kemerdekaan dengan berbuat yang bermanfaat untuk bangsa dan negara dan diri sendiri

d. Setiap hari besar seperti hari pahlawan, proklamasi kemerdekaan anak-anak dibimbing untuk mengenang jasa pahlawan dan mendoakan, semoga arwahnya diterima disisi Allah SWT

e. Mengajarkan pada anak untuk mengikuti upacara

f. Mengajarkan kepada anak untuk memelihara semangat, tekad, disiplin

g. Mengajarkan kepada anak untuk mengikuti gerakan pramuka.

\section{Nilai Mandiri}

a. Anak ditanamkan sikap patriotisme, ini harus terintegrasi dalam sikap dan kepribadian sebagai pribadi yang jujur, setia, suka menolong, dan berani menolak jika ada yang salah atau tidak benar

b. Berikan penghargaan pada anak jika dia berprestasi baik di sekolah maupun di lingkungan masyarakat khususnya di SDIT Al-Islam Kampung Suntu Kota Bima.

c. Tidak ada kata terlambat dalam belajar

d. Membiasakan bekerja dengan jujur, amanah sesuai dengan perintah

e. Menanamkan sikap untuk mengutamakan kepentingan umum dari pada kepentingan pribadi dan golongan

f. Guru ngaji mengajarkan pada anak untuk berbuat baik

g. Guru ngaji mengajarkan pada anak untuk bekerja seperti berkebun dihalaman rumah, dan membersihkan rumah 


\section{Nilai Gotong Royong}

a. Mendatangi rumah/tempat kegiatan sohibul hajat, tetangga yang sakit

b. Memberikan dukungan/bantuan sesuai kebutuhan dan kesepakatan

c. Melibatkan diri pada kegiatan kemasyarakatan untuk meringankan bebanya

d. Menghidupkan kembali budaya atau saling membantu tanpa upah

e. Membersihkan tempat pemakan umum

f. Membersihkan tempat-tempat ibadah, saluran air dilingkungan sekitar

g. Melibatkan diri secara sadar atau saling membantu dalam memakamkan warga yang meninggal dunia

\section{Urgensinya Nilai-nilai Al-Qur'an Dalam Pembentukan Karakter Siswadi SDIT Al-Islam}

1. Membaca Al-Qur'an dapat mengantarkan kita masuk syurga

2. Membaca Al-Qur'an dapat mengingat kita kepada Allah SWT

3. Membaca Al-Qur'an dapat menentramkan jiwa

4. Membaca Al-Qur'an dapat meningkatkan iman dan taqwa kepada Allah SWT

5. Membaca Al-Qur'an sebagai obat penyakit hati

6. Membaca Al-Qur'an sebagai pembersih rohani

7. Membaca Al-Qur'an sebagai petunjuk

8. Membaca Al-Qur'an sebagai cahaya ilmu

9. Membaca Al-Qur'an dapat dijadikan sebagai ibadah

Dengan adanya nilai-nilai karakter dan nilai-nilai Al-Qur'an pada siswa-siswi di atas maka penulis merumuskan nilai-nilai karakter dan nilai-nilai Al-Qur'an yang dimiliki oleh siswa-siswi adalah nilai yang tidak dapat dipisahkan dalam jiwa. Jadi karate siswa sudah dilandasi dengan nilai-nilai, nilai integritas, nilai nasionalis, nilai mandiri, nilai gotong royongdan nilai-nilai Al-Qur'an yakni; dapat mengantarkan kita masuk syurga, dapat mengingatkan kita kepada Allah SWT, dapat menentramkan jiwa, dapat meningkatkan iman dan taqwa kepada Allah 
SWT, sebagai obat penyakit hati, sebagai pembersih rohani, sebagai petunjuk, sebagai petunjuk, sebagai cahaya ilmu, dapat dijadikan sebagai ibadah, Nilai tersebut ibaratkan kulit dengan daging. Sehingga dalam sikap sudah menjadi kepribadian siswa-siswi dalam kehidupanseharihari. Penanaman nilai-nilai karakter dan nilai-nilai Al-Qur'an secara istiqomah dan berakhlak mulia. Kendati demikian, dengan sendirinya akan menjadipenyelamat sertadapat menghidupkan kembali nilai-nilai karakter peserta didik.

\section{SIMPULAN}

Berdasarkan pembahasan dapat disimpulkan bahwasanya penanaman nilai-nilai karakter dan nilai-nilai Al-Qur'an sebagai pembinaan karakter siswa melalui pembiasaan membaca Al-Qur'an sebelum belajar di SDIT AL-ISLAM Kampung Suntu Kecamatan Rasanae Barat Kota Bimasebagai pembinaan karakter baik itu aqidahnya maupun akhlak siswa/peserat didik sangatlah penting dilakukan pada setiap jenjang lembaga pendidikan, agar seorang peserta didik/siswa memiliki kepribadian yang baik dan terhindar dari pelanggaranpelanggaran moral, maka perlu adanya penguatan nilai-nilai karakter siswa/anak didik sejak dini. Di sisi lain perlu adanya kerjasama guru dengan orang tua siswa dan masyarakat dalam merumuskan dan mengawal pembinaan perilaku seorang siswa. Bersamaan dengan itu pula, seorang siswa/anak didik juga dibimbing dengan nilai-nilai rohani, seperti cara tutur kata yang baik, berpakaian yang baik,bergauldenganbaik,dan lain-lain.Selain itu, pesertadidik juga ditanamkan sifat-sifat yang baik, seperti nilai-nilai karakter dan nilainilai Al-Qur'an nilai-nilai integritas, nilai nasionalis, nilai mandiri, nilai gotong-royong, nilai sabar dalam belajar pada setiap tingkat satuan pendidikan. 


\section{DAFTARUSTAKA}

Anas Salahudin,Irwanto Alkrienciehie. 2013. Pendidikan Karakter, Pendidikan Berbasis Agama dan Budaya Bangsa. Bandung Pustaka Setia.

Abdulrohman Rendi. 2010. International Journal for Islamic Educational Studies (1) 1.

Andayani Majid \& Dian 2011. Pendidikan Karakter Dalam Prespektif Islam. Bandung: PT Remaja Rosdakarya.

Adel Mohd Abdulaziz, Mohd Alwi Yusoff\& Ahmad kamel Mohamed.2010. Journal Studi Al-Quran and Islamic Educations.

Daradjat, dkk Zakiah, 1993. Dasar-dasar Agama Islam. Cet. VIII ; Jakarta : PN. Bulan Bintang.

Pusat Bahasa Departemen Pendidikan Nasional, 2008. Kamus Bahasa Indonesia. Jakarta: Pusat Bahasa.

Hassan Shadily Echolis, John M. 1987. Kamus Inggris Indonesia.Jakarta: Gramedia.

Ibrahim Hasan. 2002. Sejarah kebudayaan Islam, Penrj, H. A. Bahuddin.Jakarta: kalam Mulia.

Karen E. Bohlin dan Kevin Ryan. 1999. Buliding Character in Schools: Pratical Ways to Bring Moral Instruction to Life. San Francisco: Jossey Bass.

Koesoema A Doni. 2007. Pendidikan Karakter: Strategi Mendidik Anak di Zaman Global. Jakarta: Grasindo.

Marimba Ahmad D. 1989. Pengantar Filsafat Pendidikan Islam, (Cet. VIII ; Bandung : PT. Al-Ma'arif.

Mohd Yakub @ Zulkifli bin Haji Mohd Yusoff \& Saidi bin Mohd. AlBayan. 2008. Journal of Al-Quran \& al-Hadith 1 (6).

Mohd Aderi Che Noh \& Rohani Ahmad Tarmizi. 2009.Jurnal Pendidikan Malaysia 34(1).

Sukiman. 2003. "Pemberdayaan Pendidikan Agama Islam (PAI) di Sekolah-Sckolah Umum",dalamJurnal llmu Pendidikan lslam Kajian tentang Konsep, ProbIem dan Prospek Pendidikan lslam, Yol. 4, No. 2, Juli.

Suryapratondo Suparlan. 1984. Ilmu Jiwa Kepribadian, (Jakarta : PT. Paryu Berkah.

Thomas Lickona,1991. Educating For Character: How Our School Can Teach Respect and Responsibility. Now York, Toronto, London, Sydney, Aucland: Bantam Books.

Sabah Mustafa Sheikh Husin, Muhadarah fi Turuq Tadris Madah alTajwid. 1996.Jurnal Institiut Pengajian Tahfiz al-Qur'an, Bahagian Hal Ehwal Islam. Jabatan Perdana Menteri. 
Sudjana Nana, dan Ibrahim. 1989. Penelitian dan Penelitian Kualitatif, Bandung: Sinar Baru. 